Citation: M. Shahid, M. Taseidifar, R.M. Pashley (2020) A Study of the Bubble Column Evaporator Method for Improved Ammonium Bicarbonate Decomposition in Aqueous Solutions: Desalination and Other Techniques. Substantia 4(2) Suppl.: 49-55. doi: 10.36253/Substantia-833

Copyright: (c) 2020 M. Shahid, M. Taseidifar, R.M. Pashley. This is an open access, peer-reviewed article published by Firenze University Press (http://www.fupress.com/substantia) and distributed under the terms of the Creative Commons Attribution License, which permits unrestricted use, distribution, and reproduction in any medium, provided the original author and source are credited.

Data Availability Statement: All relevant data are within the paper and its Supporting Information files.

Competing Interests: The Author(s) declare(s) no conflict of interest.

\section{A Study of the Bubble Column Evaporator Method for Improved Ammonium Bicarbonate Decomposition in Aqueous Solutions: Desalination and Other Techniques}

\author{
Muhammad Shahid, Mojtaba Taseidifar, Richard M. Pashley* \\ School of Science, University of New South Wales, Northcott Drive, Canberra, Australia \\ ${ }^{\star}$ Corresponding author: r.pashley@adfa.edu.au
}

\begin{abstract}
A bubble column was used to study the improved thermal decomposition of $\mathrm{NH}_{4} \mathrm{HCO}_{3}$ in aqueous solution using a continuous flow of hot gas bubbles of optimum sizes (1-3 mm) produced via controlled bubble coalescence to maintain bubble size. The rapid transfer of heat from small, hot (dry) gas bubbles to the surrounding water, i.e. into a transient hot surface layer, was used as an effective and energy efficient method of decomposing ammonium bicarbonate in aqueous solution. It is shown that the continuous flow of (dry) hot gases, even at $275^{\circ} \mathrm{C}$, only heat the aqueous solution in the bubble column to about $57^{\circ} \mathrm{C}$, at which it was also established that $\mathrm{NH}_{4} \mathrm{HCO}_{3}$ has a negligible decomposition rate even with long-term exposure to this solution temperature. Hence, the effects observed appeared to be caused entirely by the effective collisions between the hot gas bubbles and the solute. It was also established that the use of high gas inlet temperatures can reduce the thermal energy requirement to only about $50 \%$ (i.e. about $575 \mathrm{~kJ} / \mathrm{L}$ ) of that reported in previous studies and less than $25 \%$ of solution boiling.
\end{abstract}

Keywords: non-boiling decomposition, bubble coalescence, transient collisions, ammonium bicarbonate.

\section{INTRODUCTION}

\subsection{Significance of solute decomposition}

This paper is concerned with optimising a range of applications that use water, be they desalination, sterilisation, reactions and more using a bubble column evaporator. The overarching goal of water treatment by decomposition is to remove unwanted substances or solutes from water affordably and robustly. For example, the decomposition of ammonium bicarbonate (with chemical formula $\mathrm{NH}_{4} \mathrm{HCO}_{3}$ ) in aqueous solution is an important and energy-intensive process in the application of forward osmosis ${ }^{1}$ and, in the regeneration of ion-exchange resins. ${ }^{2}$ For the latter application, the ion-exchange resins comprising carboxylic acid and tertiary amine groups for desalination 
can be thermally regenerated using the BCE process at a lower energy cost than with conventional methods. More recently, Shahid et al. ${ }^{3}$ studied that solutes, ammonium bicarbonate $\left(\mathrm{NH}_{4} \mathrm{HCO}_{3}\right)$ and potassium persulphate $\left(\mathrm{K}_{2} \mathrm{~S}_{2} \mathrm{O}_{8}\right)$ can be thermally decomposed in aqueous solutions using a bubble column evaporator (BCE) process at sub-boiling condition (around $45^{\circ} \mathrm{C}$ ). Fulks et al. ${ }^{4}$ and Gokel $^{5}$ studied, ammonium bicarbonate decomposition in solution over the temperature range 30-85 ${ }^{\circ} \mathrm{C}$. Complete decomposition into ammonia, carbon dioxide and water was observed above $60{ }^{\circ} \mathrm{C}$. The main decomposition reaction is:

$$
\mathrm{NH}_{4} \mathrm{HCO}_{3(\mathrm{aq})} \triangleq \mathrm{NH}_{3(\mathrm{~g})}+\mathrm{CO}_{2(\mathrm{~g})}+\mathrm{H}_{2} \mathrm{O}
$$

The decomposition rate of this solute can be readily measured from simple electrical-conductivity measurements. The decomposition of ammonium bicarbonate using the hot-gas BCE process is examined in this study.

\subsection{Significance of the bubble column evaporator (BCE)}

The bubble column evaporator (BCE) offers a good illustration of the use of a gas-liquid interface to drive fundamental processes involving heat and mass transfer. Bubble columns are devices in which a gas, often dry air, is pumped through a multi-porous sinter disc to form gas bubbles which are continuously replenished and come into intimate contact with the column solution. Dry gas bubbles in the column solution may be used simply to mix the liquid phase homogenously to attain a uniform temperature distribution or to saturate dissolved gases in the column solution. Substances can also be transferred from one phase to the other, for example when liquid reaction products are stripped from a gas: both mass- and heat-transfer processes can occur simultaneously. ${ }^{6}$

Recently, aqueous bubble column evaporators have been used for a range of new applications. These exploit the long known, but still unexplained effect of bubble bubble coalescence inhibition that occurs systematically with many salts. The effect is both ion pair and concentration dependent. In combination with the effect are size dependent bubble rise rates and rapid watervapour uptake into the bubbles. ${ }^{3,7-9}$ These phenomena together offer a variety of applications. The most striking of these we have developed are in desalination. Some of a wide range of other useful applications of the $\mathrm{BCE}^{10}$ are: a new method for the precise determination of enthalpies of vaporisation $\left(\Delta H_{\mathrm{vap}}\right)$ of concentrated salt solutions; ${ }^{7,11}$ evaporative cooling; ${ }^{8}$ a new method for thermal desalination; ${ }^{12-14}$ a novel method for sub- boiling thermal sterilization; ${ }^{7,15-19}$ a novel method for the low-temperature thermal decomposition of different solutes in aqueous solution; ${ }^{3}$ a new approach to aqueous solute precipitation in a controlled manner. ${ }^{20}$ The efficient removal of heavy metal ions in an ionspecific, ion-flotation process is a specially noteworthy advance. ${ }^{21}$ In addition, a bubble column condenser has also been designed for the production of high-quality water as condensate. ${ }^{22-24}$

\subsection{Proposed mechanism of BCE thermal decomposition}

The application of the BCE process opens up a new approach to the thermal decomposition of degradable salts in aqueous solution. The hot surface layer produced transiently on the surface of hot bubbles (see Figure 1) created in the BCE appears to play a significant role in providing high heat- and mass-transfer efficiency, since the BCE is a direct-contact evaporator. ${ }^{25}$ Degradable chemicals exposed to this hot layer can be efficiently decomposed. In addition, gaseous products are rapidly captured by the rising bubbles, due to the internal gas/vapour rotational flow produced within the rising bubbles.

Here the effectiveness of the BCE as a method for solute decomposition was assessed and quantified. Experiments were conducted using ammonium bicar-

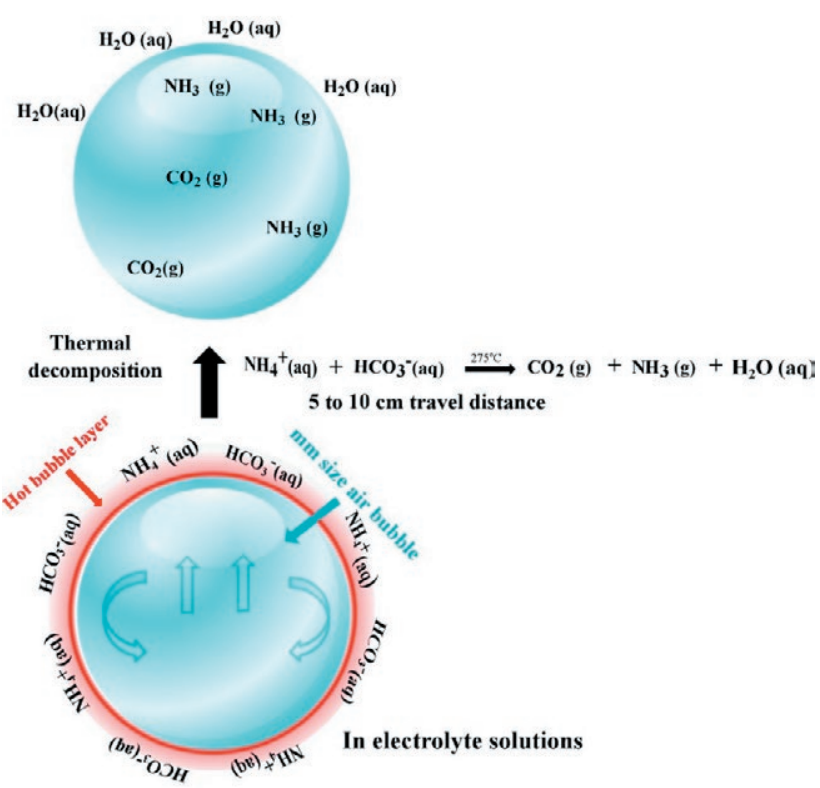

Figure 1. Schematic diagram of BCE thermal decomposition using a hot-air bubble layer. (Reprinted with permission from Ref. 3 . Copyright 2015 American Chemical Society). 
bonate at high inlet gas temperatures and a comparative study of energy cost was determined.

\section{MATERIALS AND METHODS}

\subsection{Materials}

Certified reagent-grade ( $\geq 99 \%$ purity), ammonium bicarbonate $\left(\mathrm{NH}_{4} \mathrm{HCO}_{3}\right)$ was supplied by May \& Baker Ltd and used without further purification. Aqueous solutions were prepared using deionized, ultrafiltered water (Milli-Q). At room temperature, the deionized water had a conductivity $<2.0 \mu \mathrm{S} / \mathrm{cm}$ and a natural equilibrium $\mathrm{pH}$ of 5.7. All concentrations are given in molality $(\mathrm{m})$ units.

2.2.2. Electrical conductivity measurements in standard $\mathrm{NH}_{4} \mathrm{HCO}_{3}$ solutions

Ammonium bicarbonate solutions were prepared in the range: 0.5 to $2 \mathrm{~m}$. Electrical conductivity values of all the solutions were measured using a Thermo Fisher Scientific (Waltham, MA, USA) conductivity meter at $25^{\circ} \mathrm{C}$.

\subsection{BCE system for thermal decomposition}

A high-surface-area gas/water interface was produced continuously by pumping dry gases (laboratory grade air and nitrogen separately), through a 40-100 micron pore-size glass sinter into a $120 \mathrm{~mm}$ diameter open-top glass column (Büchner type, Pyrex ${ }^{\oplus}$ Borosilicate, VWR) filled with $250 \mathrm{~mL}$ solution. The BCE apparatus used to study improved decomposition with a high-temperature gas (air) flow is shown in Figure 2. This system enables the use of inlet dry gas temperatures of more than $275^{\circ} \mathrm{C}$. The inlet air temperature was varied using a Tempco air heater $(300 \mathrm{~W})$ with a thermocouple temperature monitor and an AC Variac electrical supply. The actual temperature of the dry gas flowing into the solution was measured at the centre of the sinter by a Tenmars thermometer $\left( \pm 1.5^{\circ} \mathrm{C}\right)$ without any solution in the column. The gases (air and nitrogen) were produced by cylinder (Coregas Pty Ltd, Australia) and a BOC gas flow meter. The temperature of the column solution was also continuously monitored using a thermocouple positioned at the centre of the column solution. The air flow at temperatures of $300-600{ }^{\circ} \mathrm{C}$, was needed to produce gas temperatures just above the glass sinter up to $275^{\circ} \mathrm{C}$, and this necessitated the use of steel and brass connectors for the downstream output from

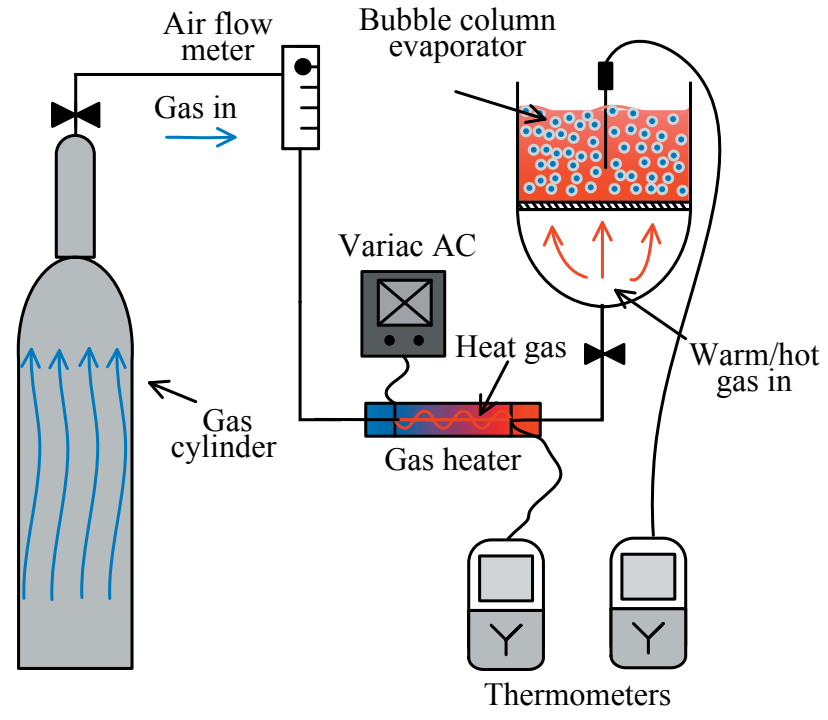

Figure 2. Schematic diagram of the bubble column evaporator (BCE) for solute decomposition. (Reprinted with permission from Ref. 3. Copyright 2015 American Chemical Society).

the heater and the use of FM Insulation Rock Wool as an insulating material.

For comparison, the effects of solution temperature on the decomposition of $\mathrm{NH}_{4} \mathrm{HCO}_{3}$ solutions was studied over time using stirred samples in a Tamson (Beiswijk, The Netherlands) heating bath at temperatures matching those of the BCE tests. During these experiments, samples were regularly taken out from the column and water bath, and their electrical conductivities and $\mathrm{pH}$ values measured using a EUTECH CON $700 \mathrm{pH}$ 700 Bench meter (Eutech Instruments Pte Ltd.).

\section{RESULTS AND DISCUSSION}

3.1. Thermal decomposition of ammonium bicarbonate solutions using a $B C E$

3.1.1. Measurement of the electrical conductivity of $\mathrm{NH}_{4} \mathrm{HCO}_{3}$ solutions at different concentrations

As the $\mathrm{NH}_{4} \mathrm{HCO}_{3}$ salt thermally decomposed into $\mathrm{NH}_{3}$ and $\mathrm{CO}_{2}$ gases, the concentration of $\mathrm{NH}_{4}{ }^{+}$and $\mathrm{HCO}_{3}{ }^{-}$reduced in the aqueous solution. So the decomposition process could be monitored through the measurement of the electrical conductivity of the samples taken from the bubble column.

The $\mathrm{pH}$ of aqueous solutions were also measured and found to be basic.

As hot dry bubbles enter the column, water vaporisation occurs, and water vapour passes into the bubbles. 
The amount of vaporised water removed, $m_{v}(\mathrm{~g})$ after time $t(\mathrm{sec})$, during a typical BCE process was estimated using the following relation:

$m_{v}=r_{f} \frac{\frac{T_{e}}{T_{f}}}{\frac{P_{e}}{P_{f}}} t \rho_{v}^{w}$

where, $r_{f}(\mathrm{~L} / \mathrm{s})$ is the room-temperature gas flow rate, measured just prior to the heater, about $22.5 \mathrm{~L} / \mathrm{min}$ in this study; $T_{c}, T_{f}$ are the gas temperatures (in $\mathrm{K}$ ) at the top of the column solution and at the flow meter; and $P_{c}$, $P_{f}$ are the corresponding pressures at the same positions. These are the factors used to estimate the "bubble column flow rise" rate. Here $\rho_{v}^{w}$ is the water-vapour density in $\mathrm{g} / \mathrm{L}$ at the temperature of the solution at the top of the column, which was calculated from the vapour pressure of the solution using the ideal gas equation.

Using the measured electrical conductivity of the $\mathrm{NH}_{4} \mathrm{HCO}_{3}$ solutions at different time intervals, the percent decomposition of $\mathrm{NH}_{4} \mathrm{HCO}_{3}$ at time $(t)$ in the $\mathrm{BCE}$ process was calculated:

Decomposition $\%=\left[1-\frac{\left[\mathrm{NH}_{4} \mathrm{HCO}_{3}\right]_{t}}{\left[\mathrm{NH}_{4} \mathrm{HCO}_{3}\right]_{0}}\right] \times 100$

Here $\left[\mathrm{NH}_{4} \mathrm{HCO}_{3}\right]_{t}$ is the concentration of $\mathrm{NH}_{4} \mathrm{HCO}_{3}$ at time $(t)$ during the $\mathrm{BCE}$ operation and $\left[\mathrm{NH}_{4} \mathrm{HCO}_{3}\right]_{0}$ is the initial concentration of $\mathrm{NH}_{4} \mathrm{HCO}_{3}$, just before pouring the solution into the bubble columns.

\subsubsection{Decomposition of $\mathrm{NH}_{4} \mathrm{HCO}_{3}$ Solutions}

Some typical decomposition results (using air and nitrogen) obtained under different solution conditions are given in Figure 3. These results clearly demonstrate that the improved $\mathrm{BCE}$ process is much more efficient for $\mathrm{NH}_{4} \mathrm{HCO}_{3}$ decomposition than the standard method using a simple stirred heating (without $\mathrm{BCE}$ ) at the same solution temperature, here around $57^{\circ} \mathrm{C}$. The results in Figure 3 obtained for quite different stirring conditions showed that the decomposition rates for simple heating (without the BCE) remained the same. This shows that the continuous mixing by the bubbling process in the BCE did not itself contribute to the $\mathrm{NH}_{4} \mathrm{HCO}_{3}$ decomposition. Different concentrations of $\mathrm{NH}_{4} \mathrm{HCO}_{3}$ were also studied, as shown in Table 1.

It was observed that the presence of $\mathrm{NH}_{4} \mathrm{HCO}_{3}$ at concentrations above about $0.5 \mathrm{~m}$ inhibited bubble coalescence to a similar degree as that at $0.17 \mathrm{M}$. (This critical concentration is the same for all 1:1 salts like $\mathrm{NaCl}$ that exhibit the fusion inhibition phenomenon ${ }^{9}$ ) It was also observed that fine (1-3 mm diameter) bub-
Table 1. Decomposition efficiency for an initial solution of $2 \mathrm{~m}$ $\mathrm{NH}_{4} \mathrm{HCO}_{3}$ solution using a heated (dry) air inlet in the BCE process.

\begin{tabular}{cccc}
\hline $\begin{array}{c}\text { Time } \\
(\mathrm{min})\end{array}$ & $\begin{array}{c}\text { Column } \\
\text { Solution } \\
\text { Temperature } \\
\left({ }^{\circ} \mathrm{C}\right)\end{array}$ & $\begin{array}{c}\text { Electrical } \\
\text { Conductivity } \\
(\mathrm{mS} / \mathrm{cm})\end{array}$ & $\mathrm{pH}$ \\
\hline 0 & Room Temp. & 85 & 7.74 \\
5 & 54.2 & 52.1 & 9.25 \\
10 & 56.7 & 28.3 & 9.44 \\
15 & 57.1 & 8.95 & 9.33 \\
20 & 57.8 & 1.57 & 8.87 \\
\hline
\end{tabular}

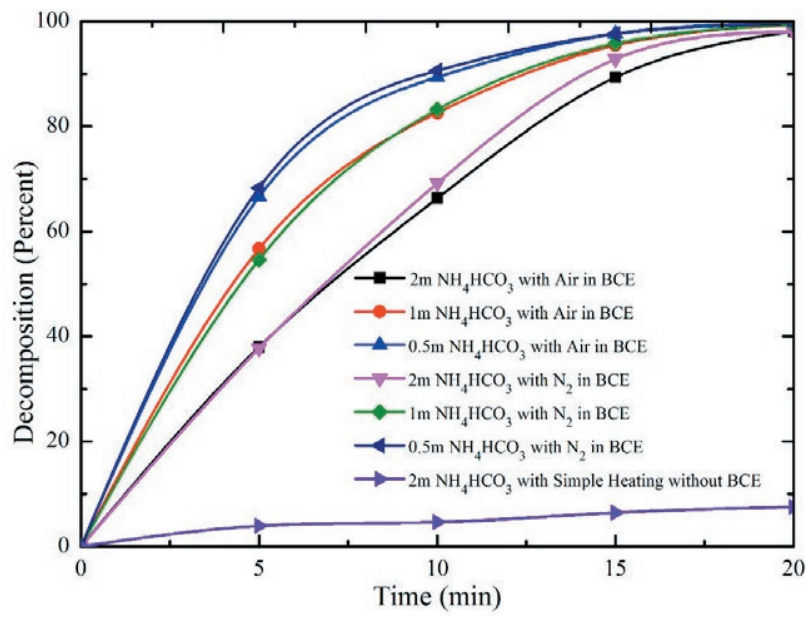

Figure 3. Percent decomposition of $\mathrm{NH}_{4} \mathrm{HCO}_{3}$ solutions at different concentrations in the BCE with an inlet gas (air and nitrogen) temperature of $275^{\circ} \mathrm{C}$ and column solution temperature of $57^{\circ} \mathrm{C}$ and in a stirred vessel for simple heating at around $57^{\circ} \mathrm{C}$.

bles were produced in the BCE process (see Figure 4a). It was clear from the photos taken during the decomposition of $2 \mathrm{~m} \mathrm{NH}_{4} \mathrm{HCO}_{3}$ solution that, after bubbling for $10 \mathrm{~min}$, the average bubble size started to increase (Figure $4 \mathrm{~b}$ ). That is expected as electrolyte concentration reduces. ${ }^{9}$ Finally, after almost complete decomposition of $\mathrm{NH}_{4} \mathrm{HCO}_{3}$ at around $20 \mathrm{~min}$, the bubble size became the same as in pure water. This provides explicit visual indication of the complete decomposition of ammonium bicarbonate in the aqueous solution (Figure 4c). The thermal decomposition of ammonium bicarbonate solutions into ammonia and carbon dioxide gas and the resulting reduction in $\mathrm{NH}_{4} \mathrm{HCO}_{3}$ concentration reflects the increase in bubble size. 


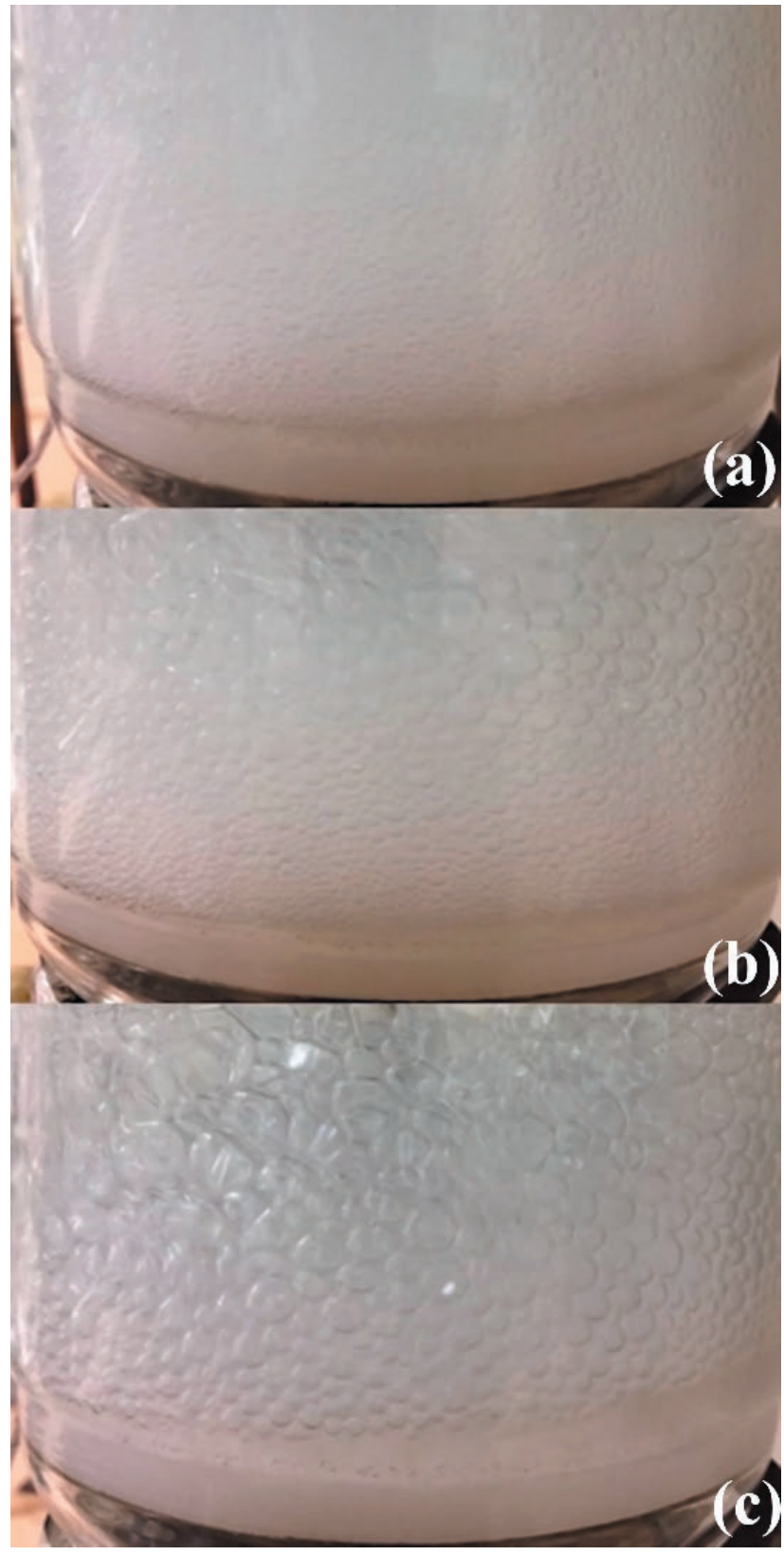

Figure 4. Photographs of the bubble sizes in $\mathrm{NH}_{4} \mathrm{HCO}_{3}$ solutions in a BCE with an inlet of (dry) air at $275^{\circ} \mathrm{C}$, at experimental times: (a) $0 \mathrm{~min}$ (b) $10 \mathrm{~min}$; and (c) $20 \mathrm{~min}$.

3.1.3. Effect of initial bubble temperature on $\mathrm{NH}_{4} \mathrm{HCO}_{3}$ decomposition in a BCE

It appears that the decomposition of $\mathrm{NH}_{4} \mathrm{HCO}_{3}$ in aqueous solutions within a hot air BCE system occurs due to the hot surface layer initially present around the stream of hot air bubbles released from the frit. We consider the likely thickness of this transient heated layer as a function of inlet air temperature. The maximum extent of the layer can be estimated for a given temperature, assuming that it is uniform, from the total heat available from the freshly released bubble. For example, for a $1 \mathrm{~mm}$ bubble we can estimate the maximum layer thickness of water heated to, say, $80^{\circ} \mathrm{C}$ by the bubbles with an initial release temperature of about $150{ }^{\circ} \mathrm{C}$ (i.e. the inlet gas temperature) as follows.

This bubble layer thickness varies with bubble size (V) and the temperatures of the inlet air, the steady state column temperature and the average temperature of the heated surface film surrounding the bubbles. The maximum heated layer thickness can be estimated using the thermal energy balance equation:

$C_{p} \Delta T V=C_{\text {water }} \Delta t 4 \pi r^{2} \rho_{w} z$

where $C_{p}, C_{w a t e r}$ are the air and water heat capacities, in units of $\mathrm{J} /\left(\mathrm{m}^{3} \times \mathrm{K}\right)$ and $\mathrm{J} /(\mathrm{kg} \times \mathrm{K})$, respectively, and $\rho_{w}$ is the liquid water mass density (in $\mathrm{kg} / \mathrm{m}^{3}$ ). $\Delta t, \Delta T$ are the transient temperature increase in the water layer and the temperature reduction within the cooling bubbles, in units of $\mathrm{K}$, respectively.

The volume of a layer of thickness $z$ around a bubble is given by $4 \pi r^{2} \rho_{w} z$, when $\mathrm{z}$ is much smaller than $\mathrm{r}$. Hence the cooling of the bubble by $\Delta T$ must determine the thickness z. For example, for bubbles cooling by 100 ${ }^{\circ} \mathrm{C}$, the maximum heated water layer thickness, heated from 20 to $80{ }^{\circ} \mathrm{C}$, is about $70 \mathrm{~nm}$. So ammonium bicarbonate could be decomposed in this surface region, as illustrated in Figure 5. When the inlet gas temperature is increased, the thickness of the surface hot water layer would also be increased, provided the mean temperature of the film and other assumptions are fixed. Consequently, the volume of the decomposition area (in the hot bubble layer) is correspondingly increased, leading directly to improved decomposition.

It is useful to estimate the thermal energy cost to produce decomposition of an ammonium bicarbonate solution. We have done this by passing $22.5 \mathrm{~L} / \mathrm{min}$ of air heated to $275{ }^{\circ} \mathrm{C}$ through a bubble column for 20 mins with 1-3 mm size bubbles. Different concentrations of ammonium bicarbonate solution were used. The heat capacity $\mathrm{C}_{\mathrm{p}}$ at a constant pressure of air in units of $\mathrm{J} / \mathrm{gK}$ can be calculated from gas heat capacity per mole. This is fairly constant with temperature. At $275^{\circ} \mathrm{C}$ this corresponds to about $1.017 \mathrm{~J} / \mathrm{gK}$ respectively. For a flow rate of $22.5 \mathrm{~L} / \mathrm{min}$, this requires a total heat to raise the temperature of gas from 20 to $275^{\circ} \mathrm{C}$ of about $144 \mathrm{~kJ}$ per $250 \mathrm{~mL}$ of solution or $575 \mathrm{~kJ} / \mathrm{L}$. By comparison, heating a litre of ammonium bicarbonate solution using different inlet gas temperatures is shown in Figure 6. 


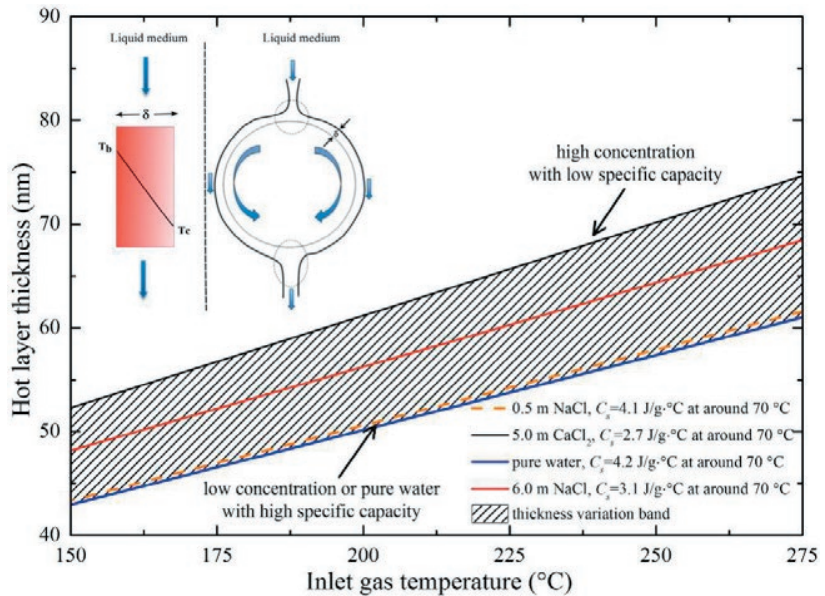

Figure 5. Relationship between the temperature of the inlet gas and the estimated thickness of the transient hot bubble surface layer around a $1 \mathrm{~mm}$ radius bubble in pure water, $0.5 \mathrm{~m} \mathrm{NaCl}$ and $5.0 \mathrm{~m}$ $\mathrm{CaCl}_{2}$. Reprinted by permission of the publisher (Taylor \&Francis Ltd, http://www.tandfonline.com) from Ref. 10.

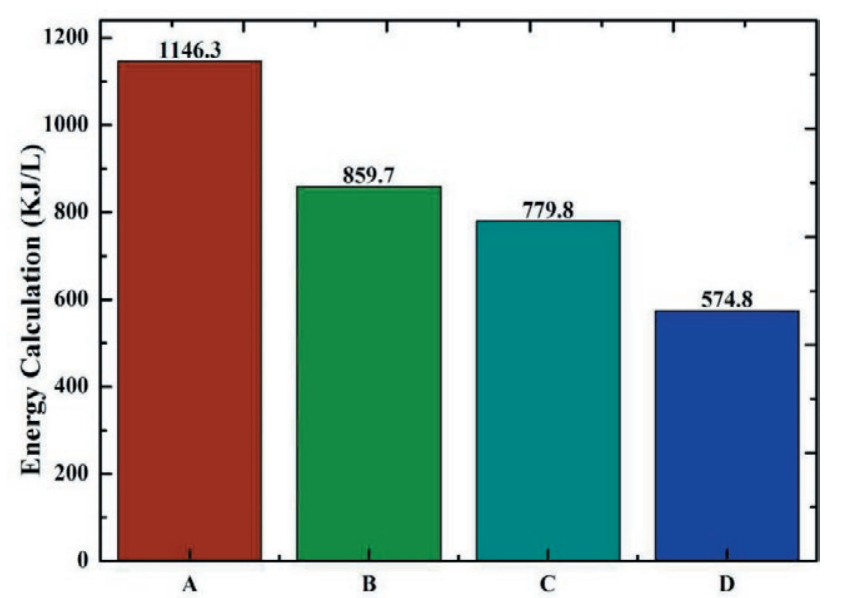

Figure 6. Comparison of thermal energy cost using air as carrier gas; $\mathrm{A}$ indicates energy cost at $150{ }^{\circ} \mathrm{C}$ inlet gas temperature using $2 \mathrm{~m} \mathrm{AB}$ solution; $\mathrm{B}$ shows at $150^{\circ} \mathrm{C}$ inlet gas temperature with $1 \mathrm{~m} \mathrm{AB}$ solution; $\mathrm{C}$ illustrates at $150{ }^{\circ} \mathrm{C}$ inlet gas temperature with $0.5 \mathrm{~m} \mathrm{AB}$ solution and $\mathrm{D}$ explains energy cost at $275^{\circ} \mathrm{C}$ using $2 \mathrm{~m} \mathrm{AB}$ solution.

\section{CONCLUSIONS AND FUTURE WORK}

A method for sub-boiling, thermal decomposition of ammonium bicarbonate solutions was presented. This is a considerable improvement on standard methods. We have shown that a bubble column can rapidly exchange heat from hot gas bubbles to the nearby water surrounding the bubbles. This can be used as an effective and energy efficient method of decomposing ammonium bicarbonate in solution. It can be readily scaled up to

treat industrial ammonium bicarbonate draw solutions used in forward osmosis desalination.

An important inference is this: The BCE process, in addition to those applications already mentioned, might also be used to destroy unwanted solutes. Hormones and pharmaceutical compounds present in wastewater present intractable problems for city water recycling. Conventional technologies do not effectively treat these contaminants. Antibiotic residues from human consumption or intensive farming can contribute to the development of antibiotic-resistant bacteria. Protozoa, residual pharmaceutical compounds and hormones are believed to have potential risks to humans and the environment. Examples of such treatments with $\mathrm{CO}_{2}$ are given in other papers in this volume. The possibilities of achieving very high temperatures within bubbles say with oxygen to carry out reactions at low cost are open.

\section{NOMENCLATURE}

\section{Abbreviations}

$\mathrm{AB}$

$\mathrm{BCE}$

Symbols

${ }^{\circ} \mathrm{C}$

$\mathrm{M}$

$\mathrm{m}$

$n$

$T$

$\Delta H_{\text {vap }}$

$\Delta P \quad$ Pressure difference between inside and outside of the bubble

$\Delta T \quad$ Temperature difference between inlet gas and bubble column solution

\section{ACKNOWLEDGMENT}

We would like to thank the Australian Research Council for funding this project.

\section{REFERENCES}

1. J. R. McCutcheon, R. L. McGinnis, and M. Elimelech, A novel ammonia-carbon dioxide forward (direct) osmosis desalination process, Desalination, 2005, 174(1), 1-11. 
2. N. P. G. N. Chandrasekara and R. M. Pashley, Study of a new process for the efficient regeneration of ion exchange resins, Desalination, 2015, 357, 131-139.

3. M. Shahid, X. Xue, C. Fan, B.W. Ninham, and R.M. Pashley, Study of a novel method for the thermolysis of solutes in aqueous solution using a low temperature bubble column evaporator, J. Phys. Chem. B, 2015, 119 (25), 8072-8079.

4. G. Fulks, G. B. Fisher, K. Rahmoeller, M. C. Wu, E. D'Herde, J. Tan, A review of solid materials as alternative ammonia sources for lean NOx reduction with SCR, 2009, SAE Technical Paper.

5. G. W. Gokel, Dean's handbook of organic chemistry. McGraw-Hill New York, 2004, 71375937.

6. P. Zehner and M. Kraume, Bubble columns, Ullmann's Encyclopedia of Industrial Chemistry, 2000.

7. C. Fan, M. Shahid, R.M. Pashley, Studies on bubble column evaporation in various salt solutions, J. Sol. Chem., 2014, 43(8), 1297-1312.

8. M. Francis, R. Pashley, Application of a Bubble Column for Evaporative Cooling and a Simple Procedure for Determining the Latent Heat of Vaporization of Aqueous Salt Solutions, J. Phys. Chem. B, 2009, 113(27), 9311-9315.

9. V. S. J. Craig, B. W. Ninham, R. M. Pashley, The effect of electrolytes on bubble coalescence in water, J. Phys. Chem. , 1993, 97(39), 10192-10197.

10. M. Shahid, C. Fan, R. M. Pashley, Insight into the bubble column evaporator and its applications, Int. Rev. Phys. Chem. , 2016, 35(1), 143-185.

11. C. Fan and R. M. Pashley, Precise Method for Determining the Enthalpy of Vaporisation of Concentrated Salt Solutions Using a Bubble Column Evaporator, J. Sol. Chem., 2015, 44(1), 131-145.

12. M. J. Francis, R. M. Pashley, Thermal desalination using a non-boiling bubble column, Desalin. Water Treat., 2009, 12(1-3), 155-161.

13. M. Shahid, R. M. Pashley, A study of the bubble column evaporator method for thermal desalination, Desalination, 2014, 351, 236-242.

14. M. Taseidifar, M. Shahid, R. M. Pashley, A study of the bubble column evaporator method for improved thermal desalination, Desalination, 2018, 432, 97-103.

15. X. Xue and R.M. Pashley, A study of low temperature inactivation of fecal coliforms in electrolyte solutions using hot air bubbles, Desalin. Water Treat., 2015, $1-11$.

16. M. Shahid, A study of the bubble column evaporator method for improved sterilization, J. Water Process. Eng., 2015, 8, 1-6.

17. A. G. Sanchis, M. Shahid, and R. M. Pashley, Improved virus inactivation using a hot bubble col- umn evaporator (HBCE), Colloids and Surfaces B: Biointerfaces, 2018, 165, 293-302.

18. A. G. Sanchis, R. M. Pashley, B. W. Ninham, Virus and bacteria inactivation by $\mathrm{CO}_{2}$ bubbles in solution, NPJ Clean Water, 2019, 2(1), 5.

19. M. Shahid, R. M. Pashley, M. Rahman, Use of a high density, low temperature, bubble column for thermally efficient water sterilisation, Desalin. Water Treat., 2014, 52, 4444-4452.

20. C. Fan, R. M. Pashley, The controlled growth of calcium sulfate dihydrate (gypsum) in aqueous solution using the inhibition effect of a bubble column evaporator, Chem. Eng. Sci., 2016, 142, 23-31.

21. M. Taseidifar, F. Makavipour, R. M. Pashley, A. F. M. M. Rahman, Removal of heavy metal ions from water using ion flotation, Environ. Technol. Innov., 2017, 8, 182-190.

22. P. N. Govindan, G. P. Thiel, R. K. McGovern, J. H. Lienhard, M. H. Elsharqawy, Bubble-Column Vapor Mixture Condenser. Google Patents.

23. G. P. Narayan, J. H. Lienhard, Thermal Design of Humidification-Dehumidification Systems for Affordable Small-Scale Desalination, IDA J. Desalin. Water Reuse, 2012, 4(3), 24-34.

24. M. Schmack, H. Goen, and A. Martin, A Bubble Column Evaporator with Basic Flat-plate Condenser for Brackish and Seawater Desalination, Environ. Technol., 2015 37(1), 74-85.

25. C. P. Ribeiro, P. L. C. Lage, Gas-Liquid Direct-Contact Evaporation: A Review, Chem. Eng. Technol., 2005, 28(10), 1081-1107. 